\title{
MODERN APPROACHES TO CLASSIFICATION OF TELEVISION CONTENT
}

Summary: Program classification is an important tool for records and marketing. Accessible, reliable, and internationally comparable data is needed in all aspects of work. And this is not only a matter of program organisation but also a fundamental part of the research of the audience in terms of studying the relationship between the public and the programs.

A typology can be created according to the motives and habits, underlying the behavior of the viewer as a buyer with regard to their television preferences. It can be first considered whether the viewer is watching TV carefully or in parallel with other things, constantly changing channels, or watching a selected channel continuously. The demographic approach is formed by derived indicators and estimates, which allows to comprehensively characterize the structure and movement of the population, social, and demographic processes. In the case of studying television audiences, it is more common to deal with indicators of the number of people, gender, age, state of marriage, level of education, profession, social status, income.

A TV set, a computer, a tablet, a smartphone - all this is now television. Arranged on the air according to the broadcasting grid, we watch television programs at

Most of our people spend their leisure time watching "blue" screens. This process of media integration in free time, which has become an important economic and socio-political trend in modern society, is one of the features of the media. Analyzing the state and structure of the media industry, economists in most countries of the world have long united the media and entertainment market. Television, being a mass media, provides viewers with entertainment such as a film screening, theat- home; it is called linear viewing. However, we can also request the content we are interested in on any screen at any time, anywhere - this is non-linear viewing. Recently, in connection with the Covid-19 pandemic, even journalists have been broadcasting from home. It used to be just television but nowadays the definition of "big television" has come into use.

Television is primarily what it shows - television content that has certain characteristics. The usual division is based on the basic functions of television - informative, entertaining, and educational. However, a lot depends on the idea, thematic focus, genre structure, origin, format, and content.

The division is necessary for a greater understanding of what exactly we intend to produce according to the formula: there is an idea, what the manufacturer wants to convey to the audience, after, it is necessary to understand how it can be made and with what content filled directly.

This article deals with approaches to the classification of television programs.

Keywords: news and current affairs programs, social and political talk shows, entertainment shows, series and serials, format, purchase of a license, concept, television viewing.

er performance recordings, music concerts and various kinds of entertainment programs.

To begin with, we must define what we mean by modern television due to the fact that some people still perceive it as broadcasting, cable, and satellite television, which broadcasts its content to a receiver, that is, to a TV set. And they don't always think that if they watched the World Cup in the summer of 2018 on the Match TV application or Facebook videos made on Nikolskaya Street, they watched 


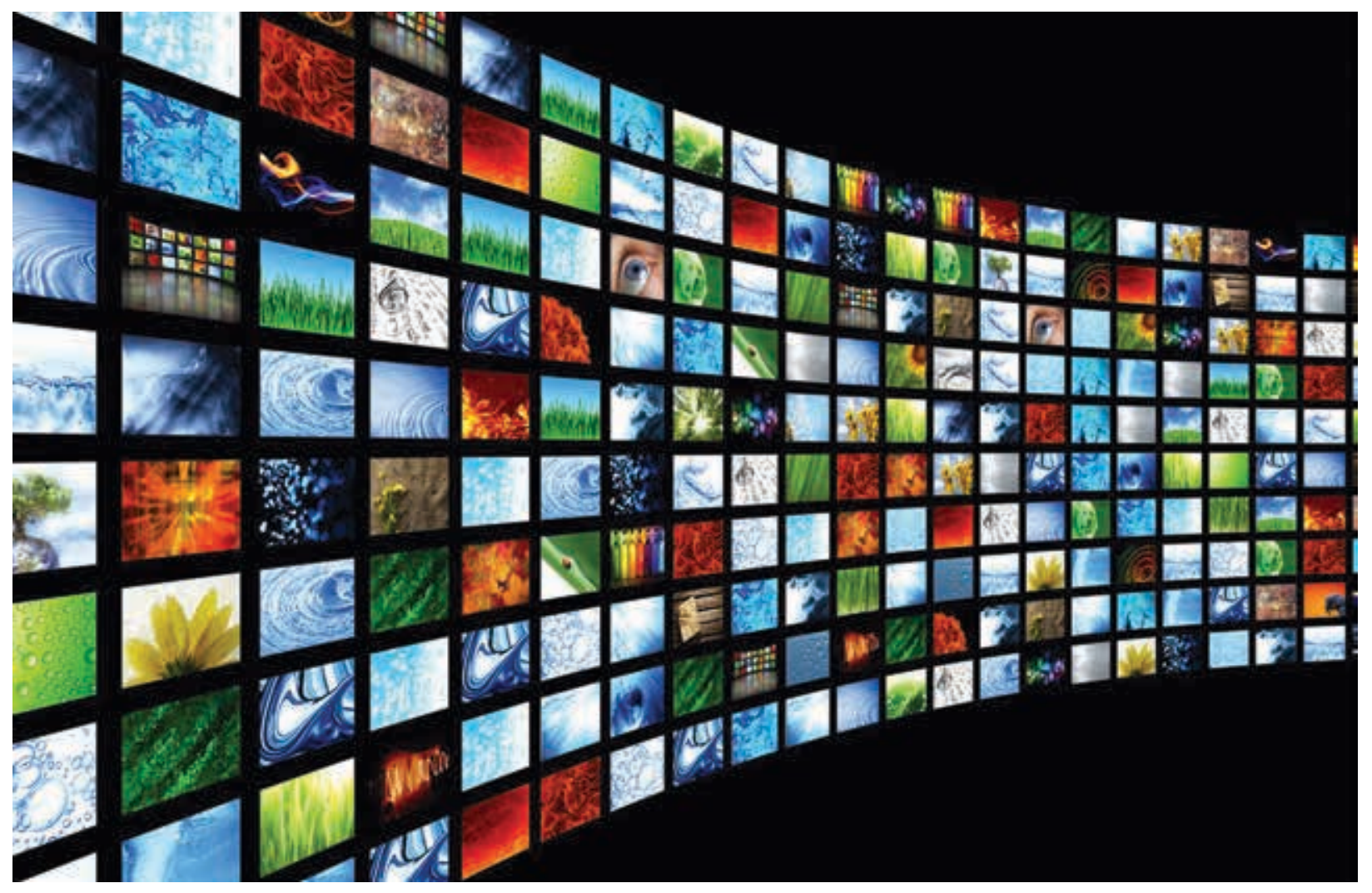

television. A TV set, a computer, a tablet, a smartphone - all this is now television. Arranged on the air according to the broadcasting grid, we watch television programs at home; it is called linear viewing. However, we can also request the content we are interested in on any screen at any time, anywhere - this is non-linear viewing. Recently, in connection with the Covid-19 pandemic, even journalists have been broadcasting from home. It used to be just television but now the definition of "big television" has come into use. The viewer can use the function of delayed viewing, following the broadcast, video on demand. Content libraries have become popular, access to which is provided by both television networks and television providers, as well as independent Internet video services that acquire rights and aggregate video content from various copyright holders. Television is primarily what it shows - television content that has certain characteristics. This is a thematic focus, genre structure, and origin (Russian, foreign or licensed content).

Digital television is an extremely competitive, commercial multi-platform ecosystem. Globalization, which currently assumes a secondary role, has led to the removal of national barriers of the integration and implementation of television production. The thematic content of TV channels primarily de- pends on the concept of the channel and, in many ways, on the main functions of television - informative, educational, and entertaining.

There are two directions of the division of television content - primary and secondary. The primary one includes television broadcasts, series, films, news, talk shows, in other words why the TV is being watched; advertising and everything shown in the inter-program broadcasting - trailers, announcements, promotions, everything owing to which the TV is watched, are the secondary one. It is they which will ultimately lead the viewer to watch, and this is successfully done on NTV, Moscow 24, STS, TNT, and many other channels. One can consider, analyze a separate program from the point of view of the goods presented to the audience; however, in the context of the TV channel, the goods are films, programs, and the presentation as well. This is its value.

Thematic, informative orientation is one of the essential characteristics of the media. Subject content is one of the most important elements of the concept of the channel. Specialization of the activities of television channels is associated with the target audience and is determined by the thematic features of the information product. Attention to typology as a scientific method is directly related to marketing research. The main type-forming factor 
is the audience orientation, the desire of TV channels to maximize the audience with a well-defined set of features - socio-demographic, with a social worldview, with specific needs, requests, interests, and preferences. The problematic and thematic focus, the appeal to certain layers of information, depends on what audience features will be given more attention. On this basis, the media can be:

- universal

- polythematic

- monothematic $[1$, p.20].

The zone of people's interests and attention, already existing in life, clear and easily explained by the name of the channel but at the same time quite broad, is the criterion for choosing the subject of the channel. The wider is the specialization, the less is its starting audience and the rate of its subsequent growth. It is impossible to calculate the degree of specialization. There are still two criteria - a strictly defined thematic niche and a wide, already existing interest in it among viewers.

Regardless of the difference in goals and objectives, the activity of television channels is aimed at maximally attracting a mass, target audience, implying the development of effective program policy. The main element is a programming strategy. TV channels fill their broadcasts according to the chosen topics and strategies. There are four basic programming strategies:

- general interest

- niche

- specialized genre-thematic

- specialized segmented.

The program policy of a channel is based on strategy and tactics. A programming strategy is a certain set of programs that corresponds to the general concept of the television channel, involving planning work for the long term, called the long-term planning what and for whom. Short-term tasks are addressed through tactics - how and when. Programming is the most important indicator of professionalism and the economic situation of a modern TV channel.

Program classification is an important tool for records and marketing. Accessible, reliable, and internationally comparable data is needed in all aspects of work. And this is not only a matter of program organisation but also a fundamental part of the research of the audience in terms of studying the relationship between the public and the programs. Television organizations of the world have always classified their programs in different ways. These classifications served mainly production purposes and were of little use for comparative analysis. Primarily, a single typology is necessary so that international broadcasting statistics can rely on it. In the sixties, the first attempt was made by UNESCO based on the principles of classification of radio broadcasts. UNESCO experts identified six typical models of television programs, according to which various countries were grouped. In the seventies, a typology based on a functional principle was proposed: information (news releases and commentary, including sports news), education (broadcasts in the framework of school and university courses, as well as for rural residents and for the purpose of lifelong learning), culture (broadcasts on religion and culture), science, entertainment programs (films, shows, music, sports), programs for a special audience, advertising. In the eighties, UNESCO finalized this classification and proposed a new one, in which an addendum aimed at improving the cultural and educational level of rural residents appeared in the part of educational programs. In terms of cultural programs, it was expected to enrich the television audience with knowledge from various areas of the national culture in non-didactic form. In addition, religious programs were regarded as a separate type.

Programs can be classified by idea, format, and content. A project can be classified according to the idea if it is an informative one, then such projects are purely informational, infotainment, and advisory. If the format is considered, then these are non-artistic projects, drama, entertainment, music, ballet, and dancing. In the first variant, it can be a newsletter, a magazine, commented events, interviews, discussions, presentations, teletext. In the second one - a dramatic production, a puppet or animation project. Entertainment formats include comic projects, programs with and without a presenter, with and without participants. As for music, ballet and dancing, these are solo performances and performances of a small ensemble, or orchestra, choral and theater music, ballet, dance.

If we consider the content, then this is a drama, or informative, entertaining, music content. Drama is the popular drama: general light drama, comedy, sitcom, soap opera, medical melodrama, action movie - adventure, disaster, detective story, thriller, epic, horror, science fiction, military, western; fantasy/fairy tales; serious drama: classic drama, modern drama; documentary drama. Informational content includes general, non-artistic topics: daily news, current events, 
weather forecasts, life and religious philosophy, social and political, economic, legal information, sports. Everything that relates to human interests: reality, show business, celebrities, personal problems. Leisure: DIY, cooking, gardening, tourism, travel, cars, keeping fit, fashion, computers. Art and media: music, sculpture, theater, cinema, advertising, press, literature, languages, history, applied sciences, natural sciences, physical sciences, medicine.

Entertainment content includes games, quizzes/ contests, pop concerts and shows, humor. Musical content is serious music: early, classical and romance, modern, light classical, jazz, pop rock, folk.

The division is necessary for a greater understanding of what exactly we intend to produce according to the formula: there is an idea, what the manufacturer wants to convey to the audience, after, it is necessary to understand how it can be made and with what content filled directly.

When considering genre classification, it can be noted that Russian broadcasters represent a diverse palette of genres. The theory of the genre is one of the most significant areas of theoretical development in art history; however, there is no single, generally accepted definition. "It is known that every genre is a historical phenomenon, that genres gradually acquire and accumulate their own attributes - the necessary and sufficient conditions for their identity; then they "live" undergoing changes; sometimes they "die", leave the living process of art, sometimes they come back to life, usually in a transformed form. However, the essence of the genre phenomenon remains incomprehensible" [2, p. 7]. Nevertheless, in most cases, we can talk about the prevailing genre and thematic strategy at the level of individual channels. These are feature films and documentaries, television series, informational and socio-political, educational programs, entertaining, children's, sports, infotainment programs, commercial, advertising, and reality shows.

R. Boretsky and V. Zwick identified genres of television information, genres of analytical journalism, and genres of artistic journalism. Basically, they are all presented on modern television but not all are used by modern journalists. TV programs in the essay genre, probably the most personalized one, can only be seen on the Russia- $K$ channel, which often broadcasts materials from the Television and Radio Fund.

As for the genre of analytical journalism - talk shows, highlighted by the authors above, it is rather a format. Talk shows are a combination of such gen- res as discussions, interviews, conversation. Some programs are emotional, a bit theatrical, such as Evening with Vladimir Solovyov (though this depends on the topic), others - The Big Game on Channel One, or Bead Game with Igor Volgin, are calmer, as in a conversation. It's quite difficult to call the last two shows entertaining, and the show, although spoken, implies this. It is rather a director's decision what the program will be like, the definition of its genre, and the form it is made in.

Television products are classified differently in different countries, although similarities are always present. The American genre classification of television products is as follows:

- information programs

- cognitive programs

- talk show

- sports programs

- game programs

- business programs

- musical programs

- children's programs

- sitcoms

- soap operas

- TV series/serials

- documentaries

- advertising and informational programs

- advertising

Russian broadcasters rate television products according to the following classification:

- daily news

- information and analytical programs

- movies

- TV series/serials

- humorous programs

- musical programs

- cognitive programs

- socio-political programs

- sports programs

- entertainment programs

- children's programs

- documentary programs [3].

If we talk about the genre structure of film screenings (imdb.com The Internet Movie Database [4]), then it is balanced on the main television channels; however, many channels focus on one genre. For example, Russia-1 channel broadcasts melodramas, NTV, and REN TV - action films. The number of comedies shown is increasing, although according to the latest official figures, they lose to detectives in the series show. STS, STS Love, and TNT chan- 
nels prefer comedies in the series show. Melodramas are in third place. The authors of the dictionary of broadcasting terms believe that a TV series is "(from Lat. series - "a row") a form of radio and television transmission, consisting of a large number of separate parts (series), each of which, as a rule, has an independent, complete plot. Such programs are usually united by common plot conflicts, the same heroes, and usually the unity of the place where the main events take place" [5]. However, TV series can be classified by genre, format, production technology, by location in the broadcasting grid, and they can be fiction or documentary. It is common for many to divide into vertical series and horizontal serials. They are called vertical when each episode is a complete story, while all the episodes are united by common characters and a cross-cutting plot. The main characters are connected by relationships that develop throughout the series. Horizontal type suggests that the episodes go out one after another several times a week, and usually the episode ends intriguingly. The Secrets of the Investigation can be attributed to Russian horizontal TV serial, but as the number of seasons increased, the serial began to change, and one story began to be divided into "film one", "film two", "part one", "part two". In Russia, historically, series are shown every day - from Monday to Thursday, or from Monday to Friday, sometimes two episodes in a row. Even purchasing Western vertical series, Russian channels put them on the grid in such a way that the series are broadcast horizontally - every weekday. Several years ago, channel One tried to broadcast series on certain days; however, their ratings began to decline and everything was returned to normal.

The division into vertical and horizontal types is more related to programming the broadcasting grid and how the channel decides to form it. According to the program grid, the horizontal is the days of the week, and the vertical is a time slot, a temporary cell, this is where the definition comes from.

The series can be classified by duration - long, short series, or a television movie (a 2-4 episode work, which can be seen, for example, on Russia-1 channel), by format and genre.

Television has historically borrowed genres from literature and cinema. Almost all of the above genres are presented in the television series. In turn, each series/serial can be attributed to several genres:

- soap opera

- sitcom
- procedural drama

- telenovela

- mini-series

- telefilm

- web series

Subgenres of sitcoms can be distinguished. A sitcom is a situational comedy, a kind of comedy radio program, where the characters and the scene are constant. For the first time, a situational comedy was aired on American radio (Sam and Henry on WGN in Chicago in 1926, and Amos \& Andy on CBS in 1928), and appeared on television during the postwar years. They were filmed with the audience, so offscreen laughter became a certain distinguishing feature. It must be admitted that this trait has also shifted to other genres (A Meeting Point, Central Television on NTV. The term sitcom appeared in 1951 with the broadcast of I Love Lucy). For the Russian audience, the most familiar adaptation sitcom is My Fair Nanny. So, the subgenres are:

- sketch com

- act-com (comedy of action)

- home-com

- dram-com (dramatic or lyrical comedy) [1, p.28]. If you classify the series by format, which is rather a classification by the number of episodes, the focus is on the type of series - telenovela, classic series, mini-series. Or the focus can be on how much the script is ready for production, for example, whether it is ready for the start of filming or is written along the way by the number of episodes; the focus can also be on timing, the frequency of broadcasting. All these divisions are directly related to the audience, the desire of TV channels to maximize an audience with a well-defined set of features. Typologization is one of the ways to study the audience for which the television content is produced. This is the identification of types (sets of common characteristic features) and the division of the audience into groups in accordance with the selected types. Thus, the entire diversity of the audience is reduced to a small, easily visible number of types. Inside the resulting groups, the audience differs by selected features less than the groups do.

The typology can be based on various grounds:

- buying behavior of the television audience;

- features of viewers' behavior on the television screen;

- demographic characteristics.

In the first option, a typology can be organised based on the motives and habits that underlie the 
behavior of the viewer as a buyer, in their connection with television preferences. In the second one, based on the information whether the viewer is watching TV carefully or in parallel with other matters, constantly switching channels or watching the selected channel inextricably. When considering the third option, demographic, it is necessary to understand that the basic indicators of demographic statistics include, first of all, indicators of the number and composition of the population, the number of births, deaths, marriages, divorces, the number of arrivals and departures from the country, as well as the number of arrivals and departures within the country and its regions. Based on this, derivative and calculated indicators are formed, allowing to comprehensively characterize the structure and movement of the population, social, and demographic processes. In the case of studying television audiences, it is more common to look at the indicators of the number of people, gender, age, marital status, level of education, profession, social status, income, property.

Russia-1 channel has a buying audience, these are men and women who are $18+$.

However, if we analyze it on the gender basis, then the female audience is $72 \%$, and the male one is respectively $28 \%$. If you classify the audience according to age criteria, then $40 \%$ are $60+$ viewers, $24 \%$ are aged $55-64,21 \%$ of the age group are $40-54,11 \%$ are from 25 to 39 years old, the remaining four percent are divided into age groups from 4 to 9 , from 10 to 15 , from 16 to 24 years. Considering the audience of the film screening, the following picture emerges: $79 \%$ of women, $21 \%$ of men. $37 \%$ aged $65+, 25 \%$ aged $55-64,21 \%$ aged $40-54$. Approximately the same indicators for series viewing with a difference in the group $65+$, there are $3 \%$ more of them, and there are $2 \%$ less of the ones in the group 40-54 [6].

According to the preferences of all viewers in broadcasting, $22 \%$ prefer television series, $29 \%$ of them are aged $55+$. The bulk of the television audience in all age groups watches Russian TV series (up to $81 \%$ ). Based on this data, the channel showing melodramas targets primarily the female audience. That is, the leaders of the channels formed a clear position that a modern Russian woman prefers just such a product - a melodrama. At the same time, preferences and real choices can show completely different results and it turns out that women of a younger age watch melodramas and action films equally. Another issue is that the preferences for action films are based on the main character, his charisma. Over the past two years, the most popular serials were: Godunov with a rating of $8.8 \%$ and a share of $24.3 \%$ with a peak of $34.6 \%$ on November 5 ; Others with a rating of $7.3 \%$ and a share of $25.4 \%$; Bad Weather with indicators of $6.6 \%$ and $19.2 \%$. Among the foreign series/serials, the first three positions are occupied by Les Miserables, Lie To Me, The Good Doctor with ratings and a share of $2.8 \%-12.2 \%, 1.3 \%-3.9 \%, 1.2 \%-3.8 \%$, respectively [6]. Characteristics of the presented serials: historical serial, drama, detective serial based on the novel of the same name by Victor Hugo, thriller/drama, medical drama. Women were the main audience of the channels on which these serials appeared.

It has to be recognized that Russia-1 channel has taken the leading position for the fourth year in a row, overtaking Channel One, which remains the most popular channel among all viewers in prime time, and this is the most expensive time for advertisers. In 2019, the largest average daily share of the audience among all viewers over 4 years of age living in large cities was again 1-11.8\%; for the closest competitor of Channel One this indicator was $10.4 \%$, for NTV $-8,9 \%$ [7].

For the first time since 2011, STS channel overtook TNT in a young audience. These two entertainment channels compete for an audience of up to 45 years, which is the most active and the most solvent. According to the data of the analytic company Mediascope for December 2019, on average, $9.36 \%$ of viewers aged $14-44$ years old or $9.45 \%$ aged $10-45$ years watched STS. TNT indicators were as follows: $9.32 \%$ of viewers and $9 \%$, respectively. The target audience of STS is 10-45 years old, and TNT is 14-44 years old. The main hits of the year 2019 on STS channel was the comedy serial Tall Girls about a women's basketball team - a new approach to the serials. There is no gloss in the sto$r y$, it is an actual plot close to life. The second hit was the renewed Fort Boyard adventure show. The Russian version of Fort Boyard was aired from 1998 to 2013 on various television channels. After a sixyear interval, STS decided to revive this show and it paid off: almost every fourth Russian audience of 10-45 years old watched the episode on October 20. According to Mediascope, this is the most popular STS program for 2019.

Conclusions: since classifications are the most important tool for reporting and marketing, it is 
necessary to base on the following classifications when studying and analyzing television content:

- the audience and its typology;

- thematic and substantive focus;

- classifications of channels by topic;
- classifications of basic program strategies;

- classifications by intention, format, content;

- genre classification of television programs;

- genre classification of films;

- genre classification of series.

\section{REFERENCES}

1. Parsadanova, T. N. 2020. Proizvodstvo televizionnogo kontenta. Aktual'nyye problemy [Producing Television Content. Actual Problems]. Moscow (in Russian)

2. Shergova, K. A. 2016. Formirovaniye dokumental'nykh televizionnykh zhanrov kino [Formation of Documentary Television Movie Genres] Available at: http://www. ipk.ru/ftpgetfile.php?id=108 (Accessed: 05.06.2020) (in Russian)

3. Based on materials of the Mediascope research company. Available at: http://mediascope.net (Accessed: 05.06.2020) (in Russian)

4. Based on materials from www.imdb.com (Accessed: 05.06.2020) (in English)

5. Glossary of terms broadcasting appeal. Available at: http:// evartist.narod.ru (Accessed: 05.06.2020) (in Russian)

6. Based on materials from http://brandmedia.ru (Accessed: 05.06.2020) (in Russian)

7. Efimovich, E. Kanal Rossiya-1 sokhranil liderstvo po auditorii sredi veshchateley [Russia-1 Channel Retained its Leadership in Terms of Audience Among Broadcasters]. Available at: http://www.rbc.ru (Accessed: 05.06.2020) (in Russian)
8. Hutchison, P. J. 2018. "When TV Became a Target: Ritual and Burlesque in Television Creature Features", Journal of Popular Film and Television, vol. 46, no.2, pp. 95-107. DOI: 10.1080/01956051.2018.1458020 (in English)

9. Kuehl, J. B. 2020. "Documentary Media: History, Theory, Practice t", Historical Journal of Film, Radio and Television, vol. 40, no. 1, pp. 233-234, DOI: 10.1080/01439685.2018.1543234 (in English)

10. Meneghetti, M. 2020. "The Paradoxes of Precarious Labour in Observational Documentaries Today", New Review of Film and Television Studies, pp. 1-24. DOI: 10.1080/17400309.2020.1738830 (in English)

11. Schoonover, K. \& Corsi, B. 2020. "Primed Real Estate: Film Producers and Land Development", Historical Journal of Film, Radio and Television, vol. 40, no. 1, pp. 129139, DOI: 10.1080/01439685.2020.1715600 (in English)

12. Stratton, J. 2020. "Death and the Spectacle in Television and Social Media", Television \& New Media, vol.21, no.1, pp. 3-24. DOI: 10.1177/1527476418810547 (in English) 
Татьяна Николаевна Парсаданов

Всероссийский государственный институт кинематографии,

кандидат экономических наук,

профессор кафедры продюсерского мастерства

e-mail: parsadanovatn@yandex.ru

Москва, Россия

ORCID 0000-0002-1079-5033

ResearcherID AAP-6400-2020

DOI: 10.36340/2071-6818-2020-16-2-19-32

\section{СОВРЕМЕННЫЕ ПОДХОДЫ К КЛАССИФИКАЦИИ ТЕЛЕВИЗИОННОГО КОНТЕНТА}

Аннотация: Классификация программ - это важный инструмент для отчётности и маркетинга. Необходимы доступные, надёжные и сопоставимые на международном уровне данные во всех аспектах деятельности. И это не только вопрос организации программ, но и фундаментальная часть исследования аудитории в части изучения отношения между публикой и программами.

Типологию можно строить по мотивам и привычкам, лежащим в основе поведения зрителя как покупателя, в связи с его телевизионными предпочтениями. Можно исходить из того, смотрит ли зритель телевизор внимательно или параллельно с другими делами, постоянно переключает каналы или смотрит выбранный неотрывно. Демографический подход формируют производные и расчётные показатели, позволяющие всесторонне охарактеризовать структуру и движение населения, социально-демографические процессы. В случае изучения телеаудитории больше привыкли затрагивать показатели численного состава населения, пол, возраст, семейное положение, уровень образования, профессию, социальное положение, доходы.

Телевизор, компьютер, планшет, смартфон - это всё теперь телевидение. Мы смотрим дома телепрограммы, выстроенные в эфире согласно сетке вещания, и это линейный просмотр, но можем также в любое время, в любом месте запросить интересующий нас

У «голубых» экранов большинство нашего населения проводит свой досуг. Это одна из особенностей медиа - процесс интеграции СМИ в свободное время, - что стало важной экономической и социально-политической тенденцией современного общества. Анализируя состояние и структуру медиаиндустрии, экономисты большинства стран мира давно объединили рынок контент на любой экран - это нелинейный просмотр. В последнее время, в связи с пандемией Covid-19, даже журналисты выходят в эфир из дома. Раньше было просто телевидение, а теперь вошло в обиход определение «большое телевидение».

Телевидение - это в первую очередь то, что оно показывает: телевизионный контент, который обладает определёнными характеристиками. Привычное деление исходит из основных функций телевидения - информационной, развлекательной и образовательной. Но многое зависит от замысла, тематической направленности, жанровой структуры, происхождения, формата и содержания.

Деление необходимо для большего понимания того, что именно мы предполагаем производить по формуле: есть замысел - то, что производитель хочет донести до аудитории, - далее необходимо понять, в какую форму его можно облачить и каким непосредственно содержанием наполнить.

О подходах к классификации телевизионных программ - в этой статье.

Ключевые слова: информационные новостные программы, общественно-политические ток-шоу, развлекательные шоу, сериальная продукция, формат, покупка лицензии, концепция, телесмотрение.

СМИ и развлечений. Телевидение, будучи средством массовой информации, предоставляет зрителям в качестве развлечения кинопоказ, запись театральных спектаклей, музыкальные концерты и разного рода развлекательные программы.

Для начала определим, что мы понимаем под современным телевидением, - ведь некоторые до сих пор воспринимают его как эфирное, 
кабельное и спутниковое телевидение, транслирующее свой контент на приёмник, то есть на телевизор. И не всегда задумываются, что если они летом 2018 года смотрели Чемпионат мира по футболу через приложение «Матч ТВ» или ролики на Facebook, снятые на Никольской улице, то они смотрели телевидение. Телевизор, компьютер, планшет, смартфон - это всё теперь телевидение. Мы смотрим дома телепрограммы, выстроенные в эфире согласно сетке вещания, и это линейный просмотр, но можем также в любое время, в любом месте запросить интересующий нас контент на любой экран - это нелинейный просмотр. В последнее время, в связи с пандемией Covid-19, даже журналисты выходят в эфир из дома. Раньше было просто телевидение, а теперь вошло в обиход определение «большое телевидение». Телезритель может прибегнуть к функции «отложенный просмотр» вслед за эфиром, видео по запросу. Популярными стали библиотеки контента, доступ к которым предоставляют как телесети и телепровайдеры, так и независимые интернет-видеосервисы, которые приобретают права и агрегируют видеоконтент разных правообладателей. Телевидение - это в первую очередь то, что оно показывает: телевизионный контент, который обладает определёнными характеристиками. Это тематическая направленность, жанровая структура и происхождение (отечественный контент, зарубежный, лицензионный).

Цифровое телевидение представляет собой крайне конкурентную, коммерческую мультиплатформенную экосистему. Глобализация, которая на сегодняшний момент уходит на второй план, привела к устранению национальных барьеров интеграции и реализации телепродукции. Тематическое наполнение телеканалов в первую очередь зависит от концепции телеканала и во многом - от основных функций телевидения: информационной, образовательной и развлекательной.

Деление телевизионного контента идет по двум направлениям: основной и второстепенный. Основной - это телевизионные передачи, сериалы, фильмы, новости, ток-шоу, то, ради чего смотрят; второстепенный - реклама и всё то, что идет в межпрограммном вещании: трейлеры, анонсы, проморолики, то, благодаря чему смотрят. Именно они в конечном итоге приведут зрителя к просмотру, как это успешно дела- ют на «НТВ», «Москва 24», «СТС», «ТНТ» и многих других каналах. Можно рассматривать, анализировать отдельную программу с точки зрения товара, представленного аудитории, но в контексте телеканала товар - это и фильмы, и программы, и оформление. В этом его ценность.

Тематическая, содержательная направленность - одна из сущностных характеристик средств массовой информации. Тематика контента - один из важнейших элементов концепции телеканала. Специализация деятельности телеканалов связана с целевой аудиторией и определяется тематическими особенностями информационного продукта. Внимание к типологии как научному методу напрямую связано с маркетинговыми исследованиями. Главный типообразующий фактор - аудиторная направленность, стремление телеканалов максимизировать аудиторию с чётко определённым набором черт - социально-демографических, социально-мировозренческих, с определёнными потребностями, запросами, интересами и предпочтениями. От того, каким аудиторным признакам будет уделяться большее внимание, зависит проблемно-тематическая направленность, обращение к определённым пластам информации. По этому признаку средство массовой информации может быть:

- универсальным;

- политематическим;

- монотематическим [1, с. 20].

Критерий выбора тематики телеканала - уже существующая в жизни зона интересов и внимания людей, чёткая и легко объяснимая самим названием канала, но при этом достаточно широкая. Чем выше специализация канала, тем меньше его стартовая аудитория и скорость её последующего роста. Рассчитать степень специализации невозможно. Критериев по-прежнему два: строго определённая тематическая ниша и широкий, уже существующий интерес к ней у телезрителей.

Независимо от различия целей и задач, деятельность телеканалов направлена на максимальное привлечение массовой, целевой аудитории, что предполагает разработку эффективной программной политики. Главный элемент - стратегия программирования. Согласно выбранной тематике и стратегии телеканалы заполняют свой эфир. Выделяют 4 базовые программные стратегии:

- общего интереса;

- нишевая; 
- специализированная жанрово-тематическая;

- специализированная сегментная.

Программная политика телеканала базируется на стратегии и тактике. Стратегия программирования - это определённый набор программ, соответствующий общей концепции телеканала, предполагающего планирование работы на длительную перспективу, перспективное планирование - что и для кого. Краткосрочные задачи решаются с помощью тактики - как и когда. Программирование - важнейший индикатор профессионализма и экономического положения современного телеканала.

Классификация программ - это важный инструмент для отчётности и маркетинга. Необходимы доступные, надёжные и сопоставимые на международном уровне данные во всех аспектах деятельности. И это не только вопрос организации программ, но и фундаментальная часть исследования аудитории в части изучения отношений между публикой и программами. Телевизионные организации мира всегда по-разному классифицировали свои программы. Эти классификации служили в основном производственным целям и оказывались малопригодными для сравнительного анализа. Единая типология необходима в первую очередь для того, чтобы на неё могла опереться международная статистика вещания. Первая такая попытка была предпринята ЮНЕСКО в 1960-е годы на основе принципов классификации радиопередач. Эксперты ЮНЕСКО выделили 6 типичных моделей телепрограмм, в соответствии с которыми и группировались различные страны. В 1970-е годы была предложена типология, основанная на функциональном принципе: информация (выпуски новостей и комментарии, включая спортивные новости), образование (передачи в рамках школьного и университетского курса, а также для сельских жителей и в целях непрерывного обучения), культура (передачи на тему религии и культуры), наука, зрелищные программы (фильмы, игровые, музыкальные, спортивные передачи), программы для специальной аудитории, реклама. В 1980-е годы ЮНЕСКО доработала эту классификацию и предложила новую, где в части образовательных программ появилось добавление - «имеющие целью повысить культурно-образовательный уровень сельских жителей». В части культурных программ предполагалось обогащение телеаудитории знаниями из различных сфер национальной культуры в недидактической форме. А также вывели в качестве отдельного вида религиозные программы.

Классифицировать программы можно по замыслу, формату, контенту (содержанию). По замыслу: если он информационный, то это чисто информационные, информационноразвлекательные и консультативные проекты. Если по формату, то это - нехудожественные проекты, драма, развлечения, музыка, балет и танцы. В первом варианте это могут быть бюллетень, журнал, комментируемые события, интервью, дискуссия, презентация, телетекст. Во втором драматическая постановка, кукольный или анимационный проект. К развлекательным форматам можно отнести комические проекты, передачи с ведущим и без, с участниками и без них. Что касается музыки, балета и танцев, то это - сольное выступление и выступление небольшого ансамбля или оркестра, хоровая и театральная музыка, балет, танцы.

Если рассматривать контент/содержание, то это драма или информационный, развлекательный, музыкальный контент. Драма - это популярная драма: общая лёгкая драма, комедия, комедия положений, «мыльная опера», медицинская мелодрама, боевик, приключения, катастрофы, детектив, триллер, эпические, ужасы, научная фантастика, военные, вестерн; фэнтези/сказки; серьёзная драма: классическая драма, современная драма; докудрама. К информационному контенту можно отнести общие, нехудожественные темы: ежедневные новости, текущие события, прогноз погоды, жизненную и религиозную философию, социально-политическую, экономическую, юридическую информацию, спорт. То, что относится к человеческим интересам: реальность, шоу-бизнес, знаменитости, личные проблемы. Досуг: сделай сам, кулинария, садоводство, туризм, путешествия, автомобили, поддержание формы, мода, компьютеры. Искусство и медиа: музыка, скульптура, театр, кино, реклама, пресса, литература, языки, история, прикладные науки, естественные науки, физические науки, медицина.

Развлекательный контент - это игры, викторины/конкурсы, эстрадные концерты и шоу, юмор. Музыкальный - серьёзная музыка: ранняя, классика и романтика, современная, лёгкая классическая, джаз, поп-рок, народная.

Это деление необходимо для большего понимания того, что именно мы предполагаем производить по формуле: есть замысел - то, что 
производитель хочет донести до аудитории; далее необходимо понять, в какую форму его можно облачить и каким непосредственно содержанием наполнить.

При рассмотрении жанровой классификации можно отметить, что российские вещатели представляют разнообразную палитру жанров. Теория жанра - одна из наиболее значимых областей теоретической разработки в искусствоведении, но единого, общепринятого определения не существует. «Известно, что каждый жанр есть явление историческое, что жанры постепенно приобретают и накапливают свои признаки - необходимые и достаточные условия своей идентичности, затем «живут», претерпевая изменения; иногда «умирают», уходят из живого процесса искусства, иногда возвращаются к жизни, обычно в преобразованном виде. Однако сущность самого феномена жанра остаётся непонятной» $[2$, с. 7]. Но в большинстве случаев можно говорить о сложившейся жанрово-тематической стратегии на уровне отдельных каналов. Это художественные и документальные фильмы, телесериалы, информационные и социально-политические, просветительские программы, развлекательные, детские, спортивные, познавательно-развлекательные программы, коммерческие, реклама и реалити-шоу.

Р.А. Борецкий и В.Л. Цвик выделяли жанры телевизионной информации, жанры аналитической публицистики и жанры художественной публицистики. В основном они все представлены на современном телевидении, но не все используются современными журналистами. Телепрограммы в жанре эссе - наверное, самом персонифицированном - можно увидеть только на канале «Россия K», который часто показывает в эфире материалы Телерадиофонда.

Что касается выделяемого указанными выше авторами жанра аналитической публицистики ток-шоу, - то всё-таки это скорее формат. Токшоу - это сочетание таких жанров, как дискуссия, интервью, беседа. Одни программы эмоциональны, немного театральны, как, например, «Вечер с Владимиром Соловьёвым» (правда, это зависит от темы), течение других («Большая игра» на Первом или «Игра в бисер» с Игорем Волгиным) более спокойное, как в беседе. Назвать две последние передачи развлекательными довольно сложно, а шоу, хоть и разговорное, подразумевает это. Это скорее режиссёрское решение передачи, определение жанра и формы, в которую его облачают.
В разных странах телепродукцию классифицируют по-разному, хотя всегда присутствует схожесть. Американская жанровая классификация телепродукции выглядит следующим образом:

- информационные программы;

- познавательные программы;

- ток-шоу;

- спортивные программы;

- игровые программы;

- бизнес-программы;

- музыкальные программы;

- детские программы;

- ситкомы;

- мыльные оперы;

- многосерийные фильмы;

- документальные фильмы;

- рекламно-информационные программы;

- реклама.

Российские вещатели оценивают телепродукцию по следующей классификации:

- ежедневные новости;

- информационно-аналитические программы;

- кинофильмы;

- телесериалы;

- юмористические передачи;

- музыкальные программы;

- познавательные программы;

- социально-политические программы;

- спортивные программы;

- развлекательные программы;

- детские передачи;

- документальные программы [3].

Если говорить о жанровой структуре кинопоказа (imdb.com The Internet Movie Database) [4], то на основных телеканалах она сбалансирована, но многие каналы делают ставку на один жанр. Например, канал «Россия-1» выпускает в эфир достаточное количество мелодрам, «НТВ» и «РЕН ТВ» - боевики. Увеличивается показ комедий, хотя, по последним официальным данным, в сериальном показе они проигрывают детективам. Каналы «СТС», «СТС Love» и «THT» в сериальном показе предпочитают комедии. На третьем месте - мелодрамы. Авторы словаря терминов радиовещания считают, что сериал - это «(от лат. Series «ряд») форма радиои телевизионной передачи, состоящей из большого количества отдельных частей (серий), каждая из которых, как правило, имеет самостоятельный, завершённый сюжет. Программы С. объединяются обычно общими сюжетными коллизиями, одними и теми же героями и обычно единством места, 
где происходят основные события» [5]. Но сериалы можно классифицировать по жанру, формату, технологии производства, расположению в сетке вещания. Они могут быль игровые или документальные. Привычно для многих деление на вертикальные и горизонтальные сериалы. Вертикальный - когда каждая серия представляет собой законченную историю, при этом они объединены общими персонажами и сквозным сюжетом. Главных героев связывают отношения, которые развиваются на протяжении всего сериала. Горизонтальный же сериал предполагает, что серии выходят друг за другом несколько раз в неделю, при этом обычно каждая из них заканчивается интригующе. К российским горизонтальным сериалам можно отнести «Тайны следствия», но по мере увеличения количества сезонов сериал начал видоизменяться, и одну историю стали разбивать на «фильм первый», «фильм второй», «часть первая», «часть вторая». В России исторически сложилось, что сериалы показывают каждый день - линейкой с понедельника по четверг или с понедельника по пятницу, иногда две серии подряд. Даже закупая западные вертикальные сериалы, российские каналы ставят их в сетку таким образом, что серии транслируются горизонтально - каждый будний день. «Первый канал» несколько лет назад попробовал ставить в эфир сериалы по определённым дням, но их рейтинги стали уменьшаться - и всё вернули «на круги своя».

Деление на вертикальные и горизонтальные сериалы больше связано с программированием сетки вещания и с тем, как канал решил её сформировать. По программной сетке горизонталь - это дни недели, а вертикаль - тайм-слот, временная ячейка (отсюда и пошло это определение).

Классифицировать сериалы можно по продолжительности: длинные, короткие сериалы или телефильм (2-4-серийное произведение, которое можно увидеть, к примеру, на канале «Россия-1»), по формату и жанру.

Телевидение исторически заимствовало жанры из литературы и кинематографа. Среди телевизионных сериалов представлены почти все вышеперечисленные жанры. В свою очередь, каждый сериал может быть отнесён к нескольким жанрам:

- «мыльная опера»;

- ситком;

- процедурная драма;

- теленовелла;
- мини-сериал;

- телефильм;

- веб-сериал.

У ситкомов можно выделить поджанры. Ситком - это комедия положений, ситуационная комедия, разновидность комедийных радио- и телепередач, где герои и место действия постоянны. Впервые ситуационная комедия вышла в эфир на американском радио («Сэм и Генри» - «Sam and Henry» - на WGN в Чикаго в 1926 году и «Амос и Энди» — «Amos \& Andy» - на CBS в 1928 году), а перешла на телевидение в послевоенные годы. Снимали её при зрителях, поэтому закадровый смех стал некой отличительной чертой. Надо признать, что эта черта перешла и в другие жанры («Место встречи», «Центральное телевидение» на НТВ. Термин «ситком» появился в 1951 году, с выходом в эфир «Я люблю Люси» («I Love Lucy»). Для российского зрителя самый знакомый адаптационный ситком - «Моя прекрасная няня». Итак, поджанры:

- скетч-ком;

- акт-ком (комедия действий);

- хоум-ком (домком);

- драм-ком (драматическая или лирическая комедия) [1, с. 28].

Если классифицировать сериалы по формату (а это скорее классификация по количеству серий), то в этом случае акцентируется внимание на виде сериала (теленовелла, классический сериал, мини-сериал), на степени готовности сценария к производству (например, он готов к началу съёмок или пишется по ходу), на количестве серий, хронометраже, периодичности выхода в эфир. Все эти деления напрямую связаны и с аудиторной направленностью, стремлением телеканалов максимизировать аудиторию с чётко определённым набором черт. Одним из способов изучения аудитории, для которой производится телеконтент, является типологизация. Это выделение типов (совокупностей общих характерных признаков) и разделение аудитории на группы в соответствии с выделенными типами. Тем самым всё многообразие аудитории сводится к небольшому, легко обозримому числу типов. Внутри получающихся групп зрители различаются по выбранным признакам слабее, чем различаются между собой группы.

В основу типологии могут быть положены различные основания:

- покупательское поведение телевизионной аудитории; 
- особенности поведения зрителя у телеэкрана;

- демографические характеристики.

В первом варианте можно строить типологию по мотивам и привычкам, лежащим в основе поведения зрителя как покупателя, в их связи с телевизионными предпочтениями. Во втором исходить из того, смотрит ли зритель телевизор внимательно или параллельно с другими делами, постоянно переключает каналы или смотрит выбранный канал неотрывно. Рассматривая третий вариант - демографический, - необходимо понимать, что к основополагающим показателям демографической статистики относятся прежде всего показатели численности и состава населения, числа родившихся, умерших, браков, разводов, численности прибывших в страну и выбывших из неё, а также числа прибытий и выбытий внутри страны и её регионов. На их основе формируются производные и расчётные показатели, позволяющие всесторонне охарактеризовать структуру и движение населения, социальнодемографические процессы. В случае изучения телеаудитории больше привыкли затрагивать показатели численного состава населения, пол, возраст, семейное положение, уровень образования, профессию, социальное положение, степень доходов, имущество.

У канала «Россия-1» баинговая аудитория это мужчины и женщины 18+. Но если анализировать её по гендерному принципу, то женская составляет $72 \%$, а мужская, соответственно, $28 \%$. Если классифицировать аудиторию по возрастным критериям, то $40 \%$ - это зрители 60+, $24 \%$ в возрасте 55-64 лет, $21 \%$ - возрастная группа 40-54 года, от 25 до 39 лет - 11\%; остальные 4\% распределяются на возрастные группы от 4 до 9, от 10 до 15, от 16 до 24 лет. Рассматривая аудиторию кинопоказа, выявляется следующая картина: $79 \%$ - женщины, 21\% - мужчины. 37\% - в возрасте $65+, 25 \%$ - 55-64, $21 \%$ - 40-54. Примерно такие же показатели по сериальному просмотру с разницей в группе $65+$ : их на $3 \%$ больше, а в группе 40-54 на 2\% меньше [6].

Согласно предпочтениям всех телезрителей, в вещании 22\% предпочитают телесериалы, 29\% из них - в возрасте 55+. Основная масса телеаудитории во всех возрастных группах смотрит российские сериалы (до 81\%). Исходя из этих данных канал, показывая мелодрамы, ориентируется в первую очередь на женскую аудиторию. То есть у руководителей каналов сформировалась чёткая позиция, что современная российская женщина предпочитает именно такой продукт - мелодраму. В то же время предпочтения и реальный выбор могут показывать совершенно другие результаты, и выяснится, что женщины более молодого возраста смотрят мелодрамы и боевики в равной степени. Другое дело, что предпочтение боевикам кроется скорее в главном герое, в харизме. За последние два года самыми популярными были сериалы: «Годунов» с рейтингом $8,8 \%$ и долей 24,3\% с пиком доли 34,6\% 5 ноября, «Другие» с рейтингом 7,3\% и долей 25,4\%, «Ненастье» с показателями 6,6\% и 19,2\%. Среди зарубежных сериалов первые три позиции занимают «Отверженные» («Les Miserables»), «Обмани меня» («Lie То Ме») и «Хороший доктор» («The Good Doctor») с рейтингами и долей $2,8 \%-12,2 \%, 1,3 \%-3,9 \%, 1,2 \%-3,8 \%$ соответственно [6]. Характеристики представленных сериалов: исторический сериал, драма, детективный сериал, по одноимённому роману Виктора Гюго, триллер/драма, медицинская драма. Основная аудитория каналов, на которых выходили эти сериалы, - женщины.

Надо признать, что канал «Россия-1» четвёртый год подряд занимает лидирующее положение, обогнав «Первый канал», который остаётся самым популярным каналом среди всех зрителей в прайм-тайм, а это самое дорогое время для рекламодателей. Наибольшая среднесуточная доля аудитории среди всех зрителей старше четырёх лет, проживающих в крупных городах, в 2019 году вновь была у «России-1» (11,8\%), у ближайшего конкурента — «Первого канала» - этот показатель составляет 10,4\%, у «НТВ» - 8,9\% [7].

Канал «СТС» впервые с 2011 года обогнал «ТНТ» по молодой аудитории. Эти два развлекательных канала конкурируют за аудиторию до 45 лет, которая является самой активной и самой платёжеспособной. По декабрьским данным за 2019 год аналитической компании Mediascope, в среднем в сутки «СТС» смотрели 9,36\% зрителей в возрасте 14-44 лет или 9,45\% в возрасте 10-45 лет. У «ТНТ» показатели составили 9,32\% и $9 \%$ зрителей соответственно. Целевая аудитория «СТС»- зрители 10-45 лет, «ТНТ» - 14-44 года. Главный хит 2019 года канала «СТС» - комедийный сериал «Дылды» о женской баскетбольной команде, новый подход к сериалам. Нет глянца, «сахарности» истории - это актуальный, близкий к жизни сюжет. Второй хит - возрождённое 
шоу приключений «Форт Боярд». Российская версия «Форта Боярд» выходила в эфире с 1998 по 2013 год на различных телеканалах. После шестилетнего перерыва «СТС» решил возродить это шоу и не прогадал: выпуск от 20 октября посмотрел почти каждый четвёртый зритель России в возрасте 10-45 лет. По данным Mediascope, это самая популярная программа «СТС» за 2019 год.

Выводы: поскольку классификации - это важнейший инструмент для отчётности и маркетинга, то, изучая и анализируя телевизионный контент, необходимо базироваться на следующих классификациях:
- аудитории и её типологизации;

- тематической и содержательной направленности;

- классификации каналов по тематике;

- классификации базовых программных стратегий;

- классификации по замыслу, формату, контенту;

- жанровой классификации телепрограмм;

- жанровой классификации фильмов;

- жанровой классификации сериалов.

\section{БИБЛИОГРАФИЯ}

1. Парсаданова Т.Н. Продюсирование телевизионного контента. Актуальные проблемы. М., 2020.

2. Шергова К.А. Становление жанров документального телекино. http://www.ipk.ru/ftpgetfile.php?id=108.

3. По материалам исследовательской компании Mediascope URL: http://mediascope.net.

4. По материалам www.imdb.com.

5. Словарь терминов радиовещания, обращение. URL: http://evartist.narod.ru.

6. По материалам URL: http://brandmedia.ru.

7. Ефимович Е. «Россия-1» сохранила лидерство по аудитории среди вещателей. URL: http://www.rbc.ru (дата обращения: 04.02.2020).

8. Hutchison, P. J. 2018. «When TV Became a Target: Ritual and Burlesque in Television Creature Features», Journal of Popular Film and Television, vol. 46, no.2, pp. 95-107. DOI: 10.1080/01956051.2018.1458020 (in English)
9. Kuehl, J. B. 2020. «Documentary Media: History, Theory, Practice t", Historical Journal of Film, Radio and Television, vol. 40, no. 1, pp. 233-234, DOI: 10.1080/01439685.2018.1543234 (in English)

10. Meneghetti, M. 2020. «The Paradoxes of Precarious Labour in Observational Documentaries Today», New Review of Film and Television Studies, pp. 1-24. DOI: 10.1080/17400309.2020.1738830 (in English)

11. Schoonover, K. \& Corsi, B. 2020. «Primed Real Estate: Film Producers and Land Development", Historical Journal of Film, Radio and Television, vol. 40, no. 1, pp. 129-139, DOI: 10.1080/01439685.2020.1715600 (in English)

12. Stratton, J. 2020. «Death and the Spectacle in Television and Social Media», Television \& New Media, vol.21, no.1, pp. 3-24. DOI: 10.1177/1527476418810547 (in English) 